\title{
Liver Cancer pT2 TNM Finding v7
}

National Cancer Institute

\section{Source}

National Cancer Institute. Liver Cancer PT2 TNM Finding V7. NCI Thesaurus. Code C90160.

Liver cancer with solitary tumor with vascular invasion or multiple tumors none more than $5 \mathrm{~cm}$ in greatest dimension. (from AJCC 7th Ed.) 